\title{
HUBUNGAN KESIAPAN BELAJAR DAN KECEMASAN MATEMATIKA TERHADAP HASIL BELAJAR MATEMATIKA SISWA SMP
}

\author{
Nailul Himmi*1, Anggi Azni \\ ${ }^{1,2}$ Program Studi Pendidikan Matematika, Fakultas Keguruan dan Ilmu Pendidikan \\ Universitas Riau Kepulauan, Batam, Kepulauan Riau, Indonesia \\ email $^{* 1}$ : nailulhimmi@ fkip.unrika.ac.id
}

\begin{abstract}
Abstrak. Penelitian ini dilakukan di SMP Kartini Batam II yang bertujuan untuk mengetahui hubungan antara kesiapan belajar dan kecemasan matematika dengan hasil belajar matematika siswa. Jenis Penelitian korelasional dengan populasi seluruh siswa di SMP Kartini II Batam dan sampel siswa SMP kelas VIII Kartini II Batam Tahun Pelajaran 2016/2017 yang diambil secara purposive sampling yaitu sebanyak 30 siswa. Instrumen penelitian berupa observasi, dokumentasi dan angket. Teknik analisis menggunakan rumus korelasi pearson product moment kemudian dilanjutkan dengan Uji $\mathrm{F}$ dan kemudian dibandingkan dengan $\mathrm{F}_{\text {tabel }}(\alpha=5 \%)$ dengan bantuan software Minitab. Hasil penelitian ini diperoleh terdapat hubungan yang signifikan antara kesiapan belajar dan kecemasan matematika dengan hasil belajar matematika siswa $\left(\mathrm{F}_{\text {hitung }}=\right.$ 19,47; P. = 0,000). Dengan besar korelasi = 0,5905 yaitu pada kategori cukup. Sehingga dapat disimpulkan semakin tinggi kesiapan belajar dan semakin kurang kecemasan matematika maka akan semakin membaik pula hasil belajar matematika yang dicapai oleh siswa tersebut dan begitu pula sebaliknya.
\end{abstract}

Kata Kunci: Kesiapan Belajar, Kecemasan Matematika, Hasil Belajar Matematika

\begin{abstract}
This research was conducted in SMP Kartini II Batam which aims to determine relationship between learning readiness and math anxiety with mathematics student learning outcomes. This research is correlational with population all of students in SMP Kartini II Batam and the sample is class VIII Kartini Batam II A.Y 2016/2017 by purposive sampling (30 students). The research instrument is observation, documentation and questionnaires. The analysis technique using the Pearson product moment correlation formula using by Minitab software with $\alpha=5 \%$. The results showed that there is a significant relationship between learning readiness and math anxiety with mathematics learning outcomes of students (of $\mathrm{F}=$ 19.47; $\mathrm{P}=0.000$ ). With a large correlation $=0.5905$ which is the category enough. So the conclution is the higher and the lower readiness to learn math anxiety it will be getting better anyway mathematics learning outcomes achieved by the students and vice versa if the lower readiness to learn and the higher the anxiety the lower math mathematics learning outcomes achieved by the students in math.
\end{abstract}

Keywords: Readiness Learning, Mathematics Anxiety, Mathematical Learning Outcomes

\section{Pendahuluan}

Sebagai proses transformasi budaya, pendidikan diartikan sebagai kegiatan pewarisan budaya dari satu generasi ke generasi lain. Selanjutnya Berdasarkan Undang-Undang RI No. 20 tahun 2003 tentang SISDIKNAS, yakni pendidikan adalah usaha sadar dan terencana untuk 
mewujudkan suasana belajar dan proses pembelajaran agar peserta didik secara aktif mengembangkan potensi dirinya untuk memiliki kekuatan dalam segala hal. Sehingga dapat disimpulkan, pendidikan adalah suatu kegiatan pewarisan budaya yang dilakukan untuk meningkat mutu sumber daya dan menghasilkan perubahan yang tetap dalam pemikiran.

Matematika adalah pengetahuan tentang penalaran logik dan berhubungan dengan bilangan dan merupakan salah satu bidang yang menduduki peranan penting. Tujuan pembelajaran matematika yang termuat dalam kurikulum 2004 (Depdiknas, 2003) adalah : (1) Melatih cara berfikir dan bernalar dalam menarik kesimpulan. (2) Mengembangkan aktifitas kreatif yang melibatkan imajinasi, institusi dan penemuan dengan mengembangkan pemikiran divergen, rasa ingin tahu, membuat prediksi dan dugaan serta mencoba-coba. (3) Mengembangkan kemampuan memecahkan masalah. (4) Mengembangkan kemampuan menyampaikan informasi dan mengkomsumsikan gagasan melalui lisan, grafik, peta dan diagram dalam menjelaskan gagasan sehingga menciptakan hasil belajar yang lebih baik.

Tujuan proses pembelajaran adalah untuk memperoleh hasil belajar. Dimana hasil belajar merupakan kemampuan internal (capability) yang meliputi pengetahuan, keterampilan, dan sikap yang telah menjadi milik pribadi seseorang dan memungkinkan seseorang itu melakukan sesuatu. Adapun hasil belajar siswa SMP Kartini II Batam semester I Tahun Pelajaran 2016/2017 tersebut terlihat pada Tabel 1:

Tabel 1. Persentase Ketuntasan Nilai Matematika Siswa SMP Kartini II pada Ujian Akhir Semester Ganjil Tahun Pelajaran 2016/2017

\begin{tabular}{cccccc}
\hline \multirow{2}{*}{ Kelas } & \multirow{2}{*}{ Jumlah Siswa } & \multicolumn{4}{c}{ KKM 72 } \\
\cline { 3 - 6 } & & 6 & 17 & \multicolumn{3}{c}{ Tidak Tuntas } \\
\cline { 3 - 6 } & 35 & 11 & 32 & 29 & 83 \\
VII A & 34 & 9 & 30 & 23 & 68 \\
VII B & 30 & 12 & 40 & 21 & 70 \\
VIII A & 30 & 3 & 12 & 18 & 60 \\
VIII B & 25 & 4 & 16 & 22 & 88 \\
IX A & 25 & $\mathbf{4 5}$ & $\mathbf{2 4}$ & $\mathbf{1 3 4}$ & 84 \\
IX B & $\mathbf{1 7 9}$ & & $\mathbf{1 3}$ & Jumlas \\
TOTAL & &
\end{tabular}

Sumber: Guru mata pelajaran matematika di SMP Kartini II Batam.

Berdasarkan Tabel 1, dapat dilihat bahwa hasil ujian akhir semester SMP Kartini II Batam belum memenuhi KKM yang telah ditentukan yaitu 72 berdasarkan ketentuan kurikulum 2013. Nilai ketuntasan ulangan harian siswa yang ditunjukkan oleh setiap kelas di sekolah SMP Kartini II Batam berbeda-beda. Hal ini terlihat dari Tabel 1 bahwa persentase siswa yang tuntas hanya sekitar $24 \%$ sedangkan persentase untuk siswa yang tidak tuntas mencapai $76 \%$. Keadaan ini menjelaskan bahwa masih rendahnya hasil belajar matematika di sekolah tersebut.

Proses pendidikan melibatkan banyak hal salah satunya adalah materi pendidikan, dalam sistem pendidikan persekolahan, materi telah diramu dalam kurikulum yang disajikan sebagai sarana pencapaian tujuan. Pencapaian suatu tujuan pendidikan bukanlah suatu hal yang mudah dan tidak akan selalu dapat berjalan dengan baik karena dalam penyelenggaraannya akan terdapat 
faktor-faktor yang mempengaruhinya. Banyak faktor yang mempengaruhi ketercapaian tujuan pendidikan, diantaranya adalah faktor intrinsik maupun dari faktor ekstrinsik. Salah satu faktor yang berasal dari intrinsik adalah kesiapan belajar dan kecemasan matematika.

Kesiapan belajar adalah keseluruhan seseorang yang membuatnya siap untuk memberi respons atau jawaban di dalam cara tertentu terhadap suatu proses belajar dan merupakan suatu kondisi yang harus mendapatkan perhatian pertama sebelum kegiatan belajar (Slameto: 2010, Sutikno: 2013, Husdarta \& Yudha: 2013). Adapun faktor kesiapan belajara menurut Slameto (2010: 113)sebagai berikut: (a) Kondisi fisik, mental dan emosional; b) Kebutuhan-kebutuhan, motif dan tujuan; c) Keterampilan, pengetahuan dan pengertian yang lain yang telah dipelajari. Sedangkan menurut Djamarah (Wahyuni: 2005) faktor-faktor kesiapan meliputi: (a) Kesiapan fisik, Misalnya tubuh tidak sakit (jauh dari gangguan lesu, mengantuk, dan sebagainya); (b) Kesiapan psikis, Misalnya hasrat untuk belajar, dapat berkonsentrasi, dan ada motivasi instrinsik; (c) Kesiapan materiil, Misalnya ada bahan yang dipelajari atau dikerjakan berupa buku bacaan, catatan dll.

Dari hasil penelitian Fitriana (2013) menyatakan bahwa permasalahan dari proses pembelajaran yaitu kurangnya kesiapan belajar siswa pada pelajaran matematika sehingga menyebabkan hasil belajar matematika siswa rendah, jika kesiapan belajar siswa kurang, maka hasil belajar matematika siswa juga akan rendah, begitu pula sebaliknya, menurut Saifullah (2013) menjelaskan bahwa kurangnya kesiapan belajar yang merupakan salah satu faktor penting dalam proses pembelajaran sehingga mengakibatkan rendahnya hasil belajar. Hal ini sesuai berdasarkan hasil observasi awal yang dilakukan peneliti di SMP Kartini II Batam tahun ajaran 2016/2017 terlihat masih banyak siswa yang tidak membawa buku pelajaran sesuai jadwal mata pelajaran hari itu. Dimana membuktikan bahwa kurangnya kesiapan belajar dari siswa dalam menerima pelajaran bukan hanya di materi pembelajaran matematika saja tetapi juga ke semua materi pembelajaran. Sehingga setiap guru perlu melakukan pengecekan kesiapan siswa seperti buku pelajaran, alat tulis ataupun kesiapan siswa dalam menerima pembelajaran yang dijelaskan oleh guru. Ditinjau dari kesiapan belajar siswa yang berasal dari dalam diri siswa itu tersebut, terlihat bahwa kesiapan belajar merupakan hal penting yang mempengaruhi dalam memperoleh hasil belajar yang baik.

Hal lain yang perlu diperhatikan selain kesiapan belajar adalah mengurangi rasa kecemasan matematika yang dialami oleh siswa. Nawangsari (Navia, 2016: 23) mengemukakan bahwa kecemasan adalah suatu kondisi yang tidak menyenangkan meliputi rasa takut, tegang, khawatir, serta tidak suka yang bersifat subjektif dan timbul karena adanya perasaan tidak aman terhadap bahaya yang diduga akan terjadi. Atkinson dkk (Sholikah: 2011) menyebutkan bahwa kecemasan adalah perasaan tidak menyenangkan, yang ditandai dengan istilah-istilah seperti kekhawatiran, keprihatinan, dan rasa takut yang kadang-kadang dialami dalam tingkatan yang berbeda-beda. Sehingga kecemasan matematika adalah perasaan-perasaan ketegangan dan kecemasan yang menyebabkan kesalahan dalam angka dan penyelesaian dari problem matematika dalam lingkup luas dalam kehidupan sehari-hari dan situasi sekolah. 
Dari penelitian Anita (2014), menyatakan bahwa terdapat pengaruh yang signifikan terhadap koneksi matematis siswa, dimana jika kecemasan matematika meningkat maka nilai untuk kemampuan koneksi matematis akan menurun, begitu pula sebaliknya. Senada dengan hasil observasi dan wawancara di SMP Kartini II Batam. Sebagian besar mengalami kecemasan matematika terlihat bahwa siswa sering merasakan gugup, tegang dan takut saat guru menjelaskan pelajaran dan menunjuk siswa untuk mengerjakannya soal yang diberikan oleh guru, bahkan mengerjakan soal latihan individu dan kecemasan itu semakin besar ketika menghadapi ulangan harian matematika, ujian semester pelajaran matematika yang juga dilandasi kurangnya pemahaman konsep awal. siswa takut tidak mampu menyelesaikan soal tersebut dengan benar dan merasa tegang ketika sedang menyelesaikan soal matematika. Ketegangan yang dialami siswa ketika menyesaikan soal matematika juga terlihat dari sikap terburu-buru siswa dalam menyelesaikan soal matematika yang berakibat pada jawaban dari siswa tersebut sering salah padahal mereka paham betul dengan maksud soal yang diberikan. Bukan hanya itu saja, siswa juga merasa kesulitan dalam berkonsentrasi ketika proses pembelajaran matematika serta bersikap ragu-ragu atau bersikap kurang yakin dengan keputusan yang akan diambilnya dalam menentukan langkah-langkah pengerjaan soal matematika yang diberikan gurunya. Sehingga demikian agar tercapainya proses pendidikan berlu diperhatikannya faktor yang mempengaruhi ketercapaian tujuan pendidikan, diantaranya adalah faktor intrinsik maupun dari faktor ekstrinsik. Dimana salah satu faktor yang berasal dari intrinsik adalah kesiapan belajar dan kecemasan matematika.

\section{Metode Penelitian}

Jenis penelitian yang digunakan dalam penelitian ini adalah korelasional. Dalam penelitian ini menjadi variabel bebas (Independent variabel) adalah kesiapan belajar $\left(X_{1}\right)$ dan kecemasan matematika $\left(X_{2}\right)$, sedangkan yang menjadi variabel terikat (Dependent variabel) adalah hasil belajar matematika $(Y)$. Penelitian ini dilakukan di SMP Kartini II Batam. Pelaksanaan penelitian ini dilakukan pada semester genap tahun pelajaran 2016/2017 bulan Februari 2017 - Maret 2017. Populasi dalam penelitian ini adalah seluruh siswa SMP Kartini II Batam Tahun Pelajaran 2016/2017 yang berjumlah 179 dengan sampel VIIIB (30 siswa) yang diambil menggunakan Purposive Sampling (Muliawan: 2014, Lubis:2013). Instrumen yang digunakan dalam penelitian ini adalah Observasi, Dokumentasi, dan Angket. Angket kesiapan belajar sebanyak 27 pernyataan dengan indikator meliputi: (1) Kesiapan Fisik; (2) Kesiapan Psikis; (3) Kesiapan Materil. Sedangkan yang angket kecemasan matematika sebanyak 35 pernyataan dengan indikator meliputi: (1) Kecemasan Psikologi; (2) Kecemasan Fisiologi; (3) Kecemasan Sosial.

Validitas instrument menggunakan Product Moment dan reliabilitas menggunakan alpha cronbach. Teknik analisis data terlebih dahulu menggunakan uji normalitas sebagai uji prasyarat untuk menentukan apakah data yang diperoleh berdistribusi normal atau tidak dengan rumus $C h i$ Kuadrat. Selanjutnya menguji hubungan kesiapan belajar matematika terhadap hasil belajar matematika, dan hubungan kecemasan belajar matematika dengan hasil belajar matematika 
dicari dengan menggunakan koefisien korelasi parsial menggunakan rumus product moment yaitu:

$$
r_{x y} \frac{n\left(\sum X Y\right)-\left(\sum X\right)\left(\sum Y\right)}{\sqrt{\left\{n \sum X^{2}-\left(\sum X\right)^{2}\right\}\left\{n \sum Y^{2}-\left(\sum Y\right)^{2}\right\}}}
$$

Riduwan (2010: 228)

Keterangan :

$$
\begin{array}{ll}
r_{x y} & =\text { Koefisien korelasi antara variabel } \mathrm{X} \text { dan Variabel } \mathrm{Y} \\
n & =\text { Banyaknya obyek yang diuji } \\
x & =\text { Skor item } \\
y & =\text { Skor total } \\
\sum \mathrm{XY} & =\text { Jumlah perkalian skor item dan skor soal } \\
\sum \mathrm{X} & =\text { Jumlah skor item } \\
\sum \mathrm{Y} & =\text { Jumlah skor total } \\
\sum \mathrm{X}^{2} & =\text { Jumlah kuadrat skor item } \\
\sum \mathrm{Y}^{2} & =\text { Jumlah kuadrat skor total }
\end{array}
$$

Menguji signifikansi dengan rumus $t_{\text {test }}$ atau $t_{\text {hitung }}$ :

$$
t_{\text {hitung }}=\frac{r \sqrt{n-2}}{\sqrt{1-r^{2}}}
$$

Keterangan:

$$
\begin{array}{ll}
\mathrm{t}_{\text {hitung }} & =\text { Nilai } \mathrm{t} \\
r & =\text { Nilai koefisien korelasi } \\
n & =\text { Jumlah sampel }
\end{array}
$$

Dengan menggunakan $\alpha=5 \%$ maka kriteria keputusannya jika $t_{\text {hitung }} \geq t_{\text {tabel }}$ berarti terdapat hubungan yang positif dan jika $t_{\text {hitung }}<t_{\text {tabel }}$ berarti tidak terdapat hubungan yang positif. Selanjutnya hasil dari korelasi kemudian hitung korelasi ganda dengan rumus menurut Riduwan (2010: 238):

$$
R_{X_{1} X_{2} Y}=\sqrt{\frac{r_{X_{1} Y}^{2}+r_{X_{2} Y}^{2}-2 \cdot r_{X_{1} Y} \cdot r_{X_{2} Y} \cdot r_{X_{1} X_{2}}}{1-r_{X_{1} X_{2}}^{2}}}
$$

Keterangan :

$R_{X_{1} X_{2} Y}=$ Korelasi antara variabel $X_{1}$ dan $X_{2}$ dengan variabel $Y$

$r_{X_{1} Y}^{2}=$ Korelasi Product moment antara $X_{1}$ dengan $Y$ dikuadratkan

$r_{X_{2} Y}^{2}=$ Korelasi Product moment antara $X_{2}$ dengan $Y$ dikuadratkan

$r_{X_{1} X_{2}}^{2}=$ Korelasi Product moment antara $X_{1}$ dengan $X_{2}$ dikuadratkan 
Dalam membantu perhitungan di atas menggunakan software Minitab. Untuk melihat nilai r akan dikonsultasikan dengan menggunakan tabel interpretasi r sebagai berikut:

\begin{tabular}{cl}
\multicolumn{2}{c}{ Tabel 2. Interpretasi Koefisien Korelasi Nilai r } \\
\hline Interval Koefisien & Tingkat Hubungan \\
\hline $0.80-1.00$ & Sangat Kuat \\
\hline $0.60-0.79$ & Kuat \\
\hline $0.40-0.59$ & Cukup Kuat \\
\hline $0.20-0.39$ & Rendah \\
\hline $0.00-0.19$ & Sangat Rendah \\
\hline
\end{tabular}

\section{Hasil Penelitian dan Pembahasan}

Adapun hasil deskripsi dari pemberian angket kesiapan matematika (27 pernyataan) dan kecemasan belajar matematika (35 pernyataan) kepada 30 siswa sebagai berikut:

Tabel 3. Deskripsi Kesiapan dan Kecemasan Belajar Siswa

\begin{tabular}{ccc} 
& Kesiapan & Kecemasan \\
\hline$N$ & 30 & 30 \\
\hline Mean & 78.37 & 65,133 \\
\hline Std.Deviation & 10,801 & 13,248 \\
\hline Minimum & 48 & 46 \\
\hline Maximum & 94 & 97 \\
\hline Sum & 2351 & 1954 \\
\hline
\end{tabular}

Selanjutnya dilakukan perhitungan uji prasyarat yaitu uji normalitas disajikan pada tabel 3 sebagai berikut:

\section{Tabel 4. Besar Hubungan dan Kategori Interpretasi}

\begin{tabular}{cccccc}
\hline Variabel & $D k$ & $\chi^{2}$ hit & $\chi^{2}$ tabel & Kaidah Keputusan & Keterangan \\
\hline$X_{1}$ & $n-1$ & 4,586 & 7,815 & $\chi^{2}$ hit $\leq \chi^{2}$ tabel & Normal \\
$X_{2}$ & $n-1$ & 7,654 & 7,815 & $\chi^{2}$ hit $\leq \chi^{2}$ tabel & Normal \\
$\mathrm{Y}$ & $n-1$ & 7,365 & 7,815 & $\chi^{2}$ hit $\leq \chi^{2}$ tabel & Normal \\
\hline
\end{tabular}

Berdasarkan tabel 4 diatas terlihat bahwa untuk ketiga variabel penelitian ini $\chi^{2}$ hitung $<\chi^{2}$ tabel sehingga asumsi normalitas untuk data penelitian ini terpenuhi. Karena data penelitian telah berdistribusi normal, maka selanjutnya dilakukan perhitungan untuk koefisien korelasi dan uji signifikansi untuk $X_{1} Y$ dan $X_{2} Y$ menggunakan software minitab dapat dilihat pada tampilan berikut: 


\section{Gambar 1. Output software minitab untuk uji korelasi $X_{1} Y$ dan $X_{2} Y$}

Ataupun jika disajikan dalam tabel 5 berikut:

Tabel 5. Hasil Uji Signifikan

\begin{tabular}{cccccc}
\hline Variabel & $\mathrm{N}$ & $r_{x y}$ & $\mathrm{Dk}$ & $\mathrm{t}_{\text {hitung }}$ & $\mathrm{t}_{\text {tabel }}$ \\
\hline$X_{1} Y$ & 30 & 0,726 & 28 & 5,585 & 2,042 \\
$X_{2} Y$ & 30 & $-0,707$ & 28 & $-5,290$ & $-2,042$
\end{tabular}

Nilai positif pada $\mathrm{r}$ di variabel $X_{1} Y$ menunjukkan hubungan yang positif yang bermakna semakin baik kesiapan belajar maka akan semakin baik pula hasil belajar dan nilai negatif pada $\mathrm{r}$ di variabel $X_{2} Y$ menunjukkan hubungan yang negatif yang bermakna semakin kurang kecemasan matematik maka akan semakin baik pula hasil belajar matematikanya. Dengan nilai $t_{\text {hitung }}>t_{\text {tabel }}$ yang berarti terdapat hubungan yang signifikan antara kesiapan belajar terhadap hasil belajar dan nilai $t_{\text {hitung }}<t_{\text {tabel }}$ berarti terdapat hubungan yang signifikan antara kecemasan matematika terhadap hasil belajar.

Dari hasil perhitungan $X_{1} Y$ dan $X_{2} Y$, dilanjutkan perhitungan hipotesis terhadap $X_{1} X_{2} Y$ menggunakan software minitab dengan output sebagai berikut:

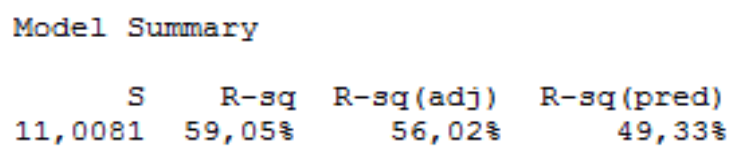

Gambar 2. Output software minitab untuk uji korelasi $X_{1} X_{2} Y$

Atupun jika disajikan dalam table 4 berikut:

Tabel 4. Hasil Perhitungan Uji Signifikansi Koefisien Korelasi Ganda

\begin{tabular}{cccccc}
\hline Variabel & $\mathrm{N}$ & $r_{x_{1,2} y}$ & $\mathrm{Dk}$ & $\mathrm{F}_{\text {hitung }}$ & $\mathrm{F}_{\text {tabel }}$ \\
\hline$X_{1} X_{2} Y$ & 30 & 0,5905 & 27 & 19,47 & 3,35 \\
\hline
\end{tabular}

Berdasarkan hasil perhitungan pada tabel 4, diperoleh koefisien korelasi ganda adalah 0,5905 dan termasuk kategori hubungan yang cukup dengan nilai $F_{\text {hitung }}(19.47)>F_{\text {tabel }}$ (3.35) sehingga dapat disimpulkan bahwa terdapat hubungan yang signifikan antara kesiapan belajar dan kecemasan matematika secara bersama-sama dengan hasil belajar matematika siswa kelas VIII SMP Kartini II Batam. Kemudian hasil analisa data perhitungan korelasi diperoleh hasil yang menyatakan terdapat hubungan kesiapan belajar dan kecemasan matematika terhadap hasil belajar matematika 
siswa kelas VIII SMP Kartini II Batam yaitu sebesar 34,87\%. Artinya adalah kesiapan belajar dan kecemasan matematika secara bersama-sama memberikan sumbangan untuk menentukan hasil belajar siswa sebesar $34,87 \%$ dan sisanya $65,13 \%$ dipengaruhi oleh faktor lain yang tidak diteliti dalam penelitian ini.

Dari penelitian ini menunjukkan bahwa jika kesiapan siswa sudah cukup dalam proses belajar matematika, siswa memiliki hasrat untuk belajar, dan menyiapkan fisik yang baik untuk dapat menerima pelajaran matematika dengan baik. Karena siswa yang memiliki kesiapan belajar yang tinggi akan dapat meningkatkan hasil belajar yang tinggi pula. Hal ini sejalan dengan hasil penelitian Bujuri (2015) yang mengatakan semakin baik kesiapan belajar siswa maka akan semakin tinggi pula prestasi belajar yang diraih, namun sebalikya semakin buruk kesiapan belajar maka semakin rendah pula prestasi belajar yang diraih. Sehingga siswa yang memiliki kesiapan belajar yang tinggi dalam belajar hidupnya akan lebih baik karena semua sudah disiapkan sesuai dengan apa yang akan dipelajari, sehingga siswa yang memiliki kesiapan belajar yang tinggi akan memiliki hasil belajar yang tinggi pula. Sedangkan siswa yang kurang memiliki kesiapan belajar akan terlihat dengan tindakannya yang kurang baik dikarenakan mereka tidak mengikuti pelajaran dengan baik. Artinya siswa yang memiliki kesiapan belajar yang tinggi dalam pelajaran matematika yang memang berpengaruh besar terhadap hasil belajar.

Sementara itu, siswa yang memiliki kecemasan matematika yang tinggi maka akan menyebabkan menurunnya hasil belajar siswa tersebut, sebaliknya jika siswa mengurangi rasa kecemasan matematika tersebut maka hasil belajar siswa tersebut akan meningkat. Menurut Durand dan Barlow (Priyani, 2013: 72) kecemasan yang masih tergolong wajar dan terkendali akan membuat siswa lebih siap dalam menghadapi pembelajaran matematika, karena kecemasan mendorong siswa untuk lebih mempersiapkan diri. Namun ketika tingkat kecemasan berlebihan dan tidak terkendali, akan berdampak buruk bagi siswa, seperti mengakibatkan siswa sulit berkonsentrasi. Hal ini juga sejalan dengan penelitian yang dilakukan oleh Priyani (2013) tinggi rendahnya prestasi belajar matematika berhubungan dengan tinggi rendahnya kecemasan menghadapi pembelajaran matematika.

\section{Kesimpulan dan Saran}

Berdasarkan hasil penelitian dan pembahasan yang telah dilakukan dapat disimpulkan terdapat hubungan yang signifikan antara kesiapan belajar dan kecemasan matematika dengan hasil belajar matematika siswa kelas VIII SMP Kartini II Batam yang diuji dengan software minitab diperoleh hasil 0,5902 atau 34,87\%. Sehingga semakin tinggi kesiapan belajar dan semakin kurang kecemasan matematika maka akan semakin membaik pula hasil belajar matematika yang dicapai oleh siswa tersebut dan begitu pula sebaliknya. Adapun saran yang diberikan dari penelitian ini adalah siswa sangat perlu untuk memahami kesadaran dirinya sendiri dan memberikan penilaian positif terhadap dirinya, sehingga dapat memupuk rasa percaya diri tanpa mengalami kecemasan yang berlebihan. Selanjutnya guru berperan serta dalam membantuk untuk memahami konsep diri siswa, mengatasi kecemasan belajar siswa dan membantu pencapaian dari hasil belajar siswa. 
PYTHAGORAS, 6(1): 22-30

April 2017

ISSN Cetak: 2301-5314

\section{Daftar Pustaka}

Anita, I.W. (2014). Pengaruh Kecemasan Matematika (Mathematics Anxiety) terhadap Kemampuan Koneksi Matematis Siswa SMP, Edujournal, Vol (3):(1).

Bujuri, A.P. (2015). Pengaruh Motivasi Belajar dan Kesiapan Belajar terhadap Prestasi Belajar Geografi SMA Swadhipa. Lampung: FKIP Universitas Lampung.

Depdiknas. (2003). Kurikulum 2004 Standart Kompetensi Mata Pelajaran.

Depdiknas. (2003). Undang-Undang RI Nomor 20, Tahun 2003, Tentang Sistem Pendidikan Nasional.

Fitriyana, E. (2013). Hubungan Antara Kesiapann Belajar dan Hasil Belajar Matematika Warga Belajar Kelas XI kelompok Belajar Paket C SKB Bondowoso Semester Genap Tahun Pelajaran 2012/2013. Bandung: Universitas Pendidikan Indonesia

Husdarta \& Yudha. (2013). Belajar dan Pembelajaran Pendidikan Jasmani dan Kesehatan. Bandung: Alfabeta

Lubis, S. (2013). Metodologi Penelitian Pendidikan. Padang : Sukabina Press.

Muliawan, J.U. (2014). Metodologi Penelitian Pendidikan. Yogyakarta: Gava Media.

Navia, Y. (2016). Hubungan antara motivasi dan kecemasan matematika terhadap hasil belajar matematika sswa kelas VIII di SMP Negeri 16 Batam T.P 2016/2017. Skripsi. Tidak diterbitkan. Universitas Riau Kepualuan, Batam.

Riduwan. (2010). Dasar-dasar Statistika. Bandung: Alfabeta.

Saifullah, A.M. (2013). Pengaruh kesiapan belajar terhadap hasil belajar matematika pokok bahasan limit pada peserta didik kelas XI semester 2 di Madrasah Aliyah Matholi'ul Huda Bugel Jepara tahun pelajaran 2012/2013. Semarang: Institut Agama Islam Negeri Walisongo.

Slameto. (2013). Belajar dan factor-faktor yang mempengaruhinya. Jakarta: Rineka Cipta.

Solikah, M. (2011). Pengaruh Kecemasan siswa pada matematika dan motivasi belajar terhadap prestasi belajar matematika. Surabaya: Universitas Negeri Surabaya.

Sutikno, S. (2013). Belajar dan Pembelajaran. Jakarta: Rineka Cipta.

Sanjaya, W. (2013). Penelitian Pendidikan Jenis, Metode dan Prosedur. Jakarta: Kencana.

Priyani, Y. (2013). Hubungan antara konsep diri dan kecemasan menghadapi pembelajaran matematika dengan prestasi belajar matematika. Yogyakarta: Universitas Negeri Yogyakarta.

Wahyuni, D. (2005). Pengaruh kesiapan belajar, motivasi belajar dan pengulangan materi pelajaran terhadap hasil belajar mata pelajaran ekonomi pada siswa kelas II MA Al Asror Gunung Pati Tahun Ajaran 2004/2005. Semarang: Universitas Negeri Semarang. 